\title{
Study on Statutory Obligations of the Intellectual Property Internet Financing Platforms
}

\author{
WeiQiong ${ }^{1, *}$ WangFeng $\mathrm{Yu}^{2}$
}

\author{
${ }^{1}$ Southwest Jiaotong University School of Public Affairs \& Law \\ ${ }^{2}$ Southwest Jiaotong University School of Public Affairs \& Law \\ *Corresponding author.Email: 310785193@qq.com
}

\begin{abstract}
Intellectual property (short for IP) pledge and $\mathrm{P} 2 \mathrm{P}$ online lending, the two online financing methods, can effectively alleviate the problem of financing the transformation of scientific and technological achievements. It is because they develop the value of the borrower's intellectual property rights to improve the borrower's repayment credit. Commonalities between the two determines that IP internet financing platforms should undertake the same statutory obligations to protect lenders and borrowers, information disclosure and most of risk management obligations undertaken by P2P online lending platforms. However, the difference between the two determines that IP internet financing platforms should not undertake the Article 10 of the "Interim Measures for the Management of Business Activities of Online Lending Information Intermediary Institutions", which prohibits to provide guarantees or promise on principal or interest; to carry out asset securitization, or to engage in equity-based crowdfunding or any other businesses. Whereas they should still undertake the statutory obligation to disclose intellectual property information used for credit enhancement. The essay suggests that the government should cooperate with the China National Intellectual Property Administration to supplement and formulate regulations, based on current ones with $\mathrm{P} 2 \mathrm{P}$ online lending, thereby to provide institutional foundation for preventing the risks of IP internet financing, and to ensure its healthy development.
\end{abstract}

Keywords: Intellectual Property online financing, P2P online lending; statutory obligation, supplementary terms.

\section{INTRODUCTION}

The intellectual property internet financing (IP internet financing for short) that uses the borrowers' intellectual properties' value to improve their repayment credit is mainly manifested in a profit-gaining business paradigm that combines intellectual property pledge and P2P online lending [1]. The business paradigm of the "ZhiShang Finance" platform is one of its examples. Following the issuance of a series of national regulations that emphasizes "financial innovation to promote technological innovation", the scale of domestic IP internet financing has grown rapidly. These documents include "In-depth Implementation of the National Intellectual Property Strategy Action Plan (2014-2020)", "Several Opinions on Deepening System and Mechanism Reform and Accelerating the Implementation of Innovation-Driven Development Strategies", "Opinions on Further Promoting Intellectual Property Financial Services", "National Innovation-driven Development
Strategy Outline", "the '13th Five-Year' National Strategic Emerging Industry Development Plan". The rapid growth in the operating data of the "ZhiShang Finance" platform shows one of its examples in the chart below.

While helping technology-based enterprises to convert their intellectual property into cash, IP internet financing may be accompanied by huge financial risks. In addition to the technical or moral risks arising from the cooperation between strangers through the Internet, there are also risks inherent in intellectual property rights itself. How to prevent these risks to ensure their healthy development, and to give play to its unique function of solving the financing problems of technology-based small and medium-sized enterprises (short for SMEs), has become a realistic problem that needs to be solved urgently in China. However, there are scarce academic research directly related to this issue, and no results have been found to specifically study the statutory obligations 
of IP internet financing platforms. Experience from developed countries such as the United States and the United Kingdom shows that enacting financial regulations can effectively lower the risks of online financing and ensure its healthy development [2]. China has issued a series of regulations that clearly stipulate the statutory obligations of P2P online lending platform [3]. Then the question is that if it is feasible to directly determine the rules for the $\mathrm{P} 2 \mathrm{P}$ online lending as the rules for the IP internet financing? For example, "Zhishang Finance" still uses the borrower's intellectual properties as pledges, promising to the lender that if overdue payment occurs, the asset management company will provide compensation services, and the guarantee company will provide overdue principal and interest advance services. It is unclear that whether business practices above will be deemed illegal in accordance with the Article 10.3 of the "Interim Measures for the Management of Business Activities of Online Lending Information Intermediary Institutions", which prohibits to provide guarantees directly or in disguised form to lenders or to guarantee principal and interest. This essay will firstly sort out the current regulations on P2P online lending, clarify the commonalities and differences between IP internet financing and $\mathrm{P} 2 \mathrm{P}$ online lending platforms, then derive regulations for the IP internet financing platforms, and lastly make suggestions to improve the laws and rules.

\section{THE MAIN CONTENT OF THE STATUTORY OBLIGATIONS FOR P2P ONLINE LENDING}

China has witnessed a brutal growth and frequent risks of $\mathrm{P} 2 \mathrm{P}$ online financing in recent years. In the light of this, China has enacted a series of regulations since 2015. The "Guiding Opinions on Promoting the Healthy Development of Internet Finance" defines P2P online lending as "individual online lending and small online loans"; and the "Interim Measures for the Management of Business Activities of Online Lending Information Intermediary Institutions" ("Interim Measures" for short) clearly stipulates the legal obligations of $\mathrm{P} 2 \mathrm{P}$ online lending platforms to prevent risks. In addition to procedural obligations such as filing and registration, its substantive obligations include three types.

The first type is the obligation to protect lenders and borrowers. As stipulated in Article 9 of the Interim Measures, platforms have the obligation to review the authenticity and legitimacy of lenders and borrowers; to prevent fraud; to popularise internet lending knowledge and promote risk education; to protect information of all parties, etc. Article 25 to 28 also stipulate obligations to prohibit unauthorised decision making; to remind lenders of risks and forbidden activities of online lending; to evaluate risks, to manage information of lenders and borrowers and keep confidential; to manage funding in isolation and to choose funding depository institutions, etc.

The second type is the obligation to disclose information, which including the obligations in Articles 30 to 32 of the Interim Measures; and that in the Guidelines for Information Disclosure of Business Activities of Online Lending Information Intermediaries.

The third type is the obligation to manage risks. These including the thirteen prohibitions (Article 10) obligations mainly for small loans (Article 17); obligation to use online channels as the main sales channel (Article 16) and the management obligation to prevent the financing platform from being exposed to technical risks (Articles 21 to 23), etc. Among which, the thirteen prohibitions from Article 10 are undoubtedly the most important. There are three that prohibit general P2P online lending platforms from going beyond the position of "information intermediary" to perform the function of "credit intermediary": the third, "it is forbidden to provide guarantees directly or in disguised form to lenders or to guarantee principal and interest"; the eighth, "it is forbidden to carry out asset-like securitization business or to assign creditor's rights in the form of packaged assets, securitized assets, trust assets, fund shares, etc."; and the twelfth, "It is forbidden to carry out equity-based crowdfunding."

\section{COMMONALITIES AND DIFFERENCES BETWEEN IP INTERNET FINANCING PLATFORMS AND P2P ONLINE LENDING PLATFORMS}

There are commonalities and differences between IP internet financing platforms and P2P online lending platforms. Logically speaking, the extent to which the former should undertake the statutory obligations assumed by the latter platform, depends on the extent to which the two actually have commonalities or differences. If the current regulations governing P2P online lending are directly applied to the supervision of IP internet financing, the differences between the two are not taken into account. For instance, If the Interim Measures are applied to the supervision of IP internet financing platforms such as "ZhiShang Finance", the operation of it's using the lender's intellectual property as a pledge, promising the borrower to provide compensation services, and overdue principal and interest advance services will be illegal, due to the violation of the prohibition in Article 10.

There are many commonalities between the two different platforms.

Firstly, they both use the Internet as their business channel. Relying on Internet operations is the most essential feature of P2P online lending, while IP internet financing also uses the Internet as the main channel for disseminating financing information. The far-reaching 
Internet financing has many advantages. Not only it enhances financial interaction between the two parties based on the information flow, but also it uses big data to discover and meet the financing needs of customers; moreover, it supplies credit services, reducing financing costs efficiently. It is these advantages that both platforms can be widely used in the financing of technology-based SMEs.

Secondly, the two platforms both can meet the financing needs of the SMEs through small investments by a large number of investors [4]. Those SMEs in the initial stage are the foundation of a country's economic development, performing irreplaceable roles in promoting economic growth and solving employment problems [5]. Many SMEs start their own businesses is because they have certain intellectual property achievements with broad market prospects, and they want to transform them into productivity to stimulates innovation. However, these SMEs are faced with the problems of lacking stable cash flow, sufficient collateral and operating performance to obtain loans from banks. Financing problems have always plagued their survival and development. Many of their disappearance is not because their projects, but because they cannot obtain sufficient funds. How to solve the financing gap between the SMEs from relying on funds of their own or borrowed from acquaintances to relying on obtaining external venture capital funds has always been a problem of concern. The emergence of internet financing provides new methods to solve this financing gap. It uses technology to eliminate information asymmetry and effectively alleviate the financing problems of the SMEs [6].

Thirdly, there are overlaps in their business operations and the positioning of their operating institutions. The financial information services provided by the two both include information collection, publication and interaction, credit evaluation, and loan matching for borrowers and lenders. Although IP internet financing must integrate the borrower's intellectual property rights with internet technology to spread financing information, like P2P online lending, it is the aggregator of all financing information and a bridge for communication between investors and financiers. "Information intermediary" is the same positioning of the two platforms.

At the same time, the two platforms have many differences. Namely, IP internet financing has the unique function of effectively solving the financing problems of technology-based SMEs.

Firstly, P2P online lending generally serves SMEs, and does not use the financier's intellectual properties as the financing basis, so there is no special function to promote the transformation of scientific and technological achievements. Moreover, the lenders are entirely at their own risk. However, IP internet financing serves technology-based SMEs, which are based on the intellectual property rights and have the function of promoting the transformation of scientific and technological achievements [7]. The risk of its investors can be shared by multiple parties [8]. In order to encourage IP financing, developed countries have established intellectual property development fund and guarantee fund system, which has formed risk burden method where risks are shared by multiple parties. Domestic scholars suggested that China should be led by the government and guided by policies to establish a multi-party participation and collaborative risk sharing model in IP internet financing, i.e., financing enterprises, internet investors, internet financing platforms, guarantee companies, asset appraisal companies, insurance institutions and other entities participating in the IP financing link should jointly bear the financing risks. China's national financing guarantee fund was established at the end of 2018, and it is one of its main functions to share the financing risks of technology-based SMEs.

Secondly, the current regulatory position P2P online lending agencies as "information intermediaries", which determines that its business is limited to information collection, exchanging and publication, credit evaluation, and loan matching. Although the IP internet financing platform can also be positioned as "information intermediary", it also has the function of "credit intermediary". That is because the most important feature of which is that intellectual properties becoming the financing basis, and the property rights in the intellectual properties owned by the borrower are integrated through pledges and other methods, to provide guarantees or credit enhancement. This feature makes the operation of the platform inevitably related to the provision of guarantees for financing or credit enhancement, making it impossible to get rid of the function of "credit intermediary".

Thirdly, although both platforms have risks from the internet, IP internet financing also has risks caused by the unstable value of intellectual property or difficulty in money-making. Information about Intellectual property rights is an important basis for lenders' decision-making [9].

\section{SCOPE OF STATUTORY OBLIGATIONS FOR INTELLECTUAL PROPERTY INTERNET FINANCING PLATFORMS}

The function of a thing, generally speaking, is that only the thing can be used to complete a certain task, or that it can be used to complete a certain task most satisfactorily [10]. The foundation for the emergence and rapid development of IP internet financing lies in the fact that it has the same functions as $\mathrm{P} 2 \mathrm{P}$ online lending, while still being different with the unique function of effectively mitigating technology-based SMEs' financing problems [11]. These functions provide a basis for determining the 
content of the legal obligations that IP internet financing platforms should undertake. In other words, the legal obligation to prevent financing risks that IP internet financing platforms are required to undertake should be limited to the extent that it does not hinder its unique functions. Measured by this standard, the scope of the legal obligations of the two platforms should logically be a cross relationship.

Firstly, IP internet financing platform should undertake the statutory obligations of the $\mathrm{P} 2 \mathrm{P}$ online lending platform that are related to the commonalities of the two. Specifically, it should firstly undertake all procedural obligations such as filing and registration from the Interim Measures. The second is to undertake all the first-category obligations (to protect lenders and borrowers) and the second-category obligations (information disclosure) from the Interim Measures. The third is to partially assume the third-category obligations (risk management), which specifically include the obligations based on micro-lending, using electronic channels as the main sales channel, and the management obligations to prevent the financing platform from being exposed to technical risks. Finally, it should also undertake seven prohibitions stipulated in Article 10 of the Interim Measures excepts No. 3, 8 and 12.

Secondly, IP internet financing platform should not undertake the statutory obligations of the P2P online lending platform that are related to the difference of the two. Although the positioning of the "information intermediary" determines that it should prohibit the collection of funds or establishing a fund pool, its "credit intermediary" function determines that it cannot undertake three prohibitions stipulated in Article 10 of the Interim Measures including No. 3, 8 and 12. Because no matter whether the two parties eventually form a loan contract (IP pledge financing) or an investment contract (IP online crowdfunding financing and IP securitization financing), they must rely on the financing party's property rights in the intellectual property rights to increase its financing credit, otherwise it will lose the unique function of effectively alleviating the financing problems of technology-based SMEs [12]. If the IP internet financing platform is forbidden to guarantee or increase credit, carry out asset-like securitization business or engage in equity-based crowdfunding business, it will lose the foundation for its existence and development [13].

Thirdly, IP internet financing platforms should also undertake statutory obligations arising from own individuality. For example, the information disclosed under its statutory obligations should include information on intellectual properties used for credit enhancement, as this information will directly affect the lender's decision [14].

\section{THE IMPROVEMENT OF REGULATIONS FOR THE IP INTERNET FINANCING PLATFORM}

Since it is not possible to directly copy the current regulatory standards for $\mathrm{P} 2 \mathrm{P}$ online lending [15], the government should absorb applicable content in the current regulations, exclude inapplicable rules, and add content specific to intellectual property internet financing by formulating additional regulations, thus to improve regulations for IP Internet Financing platform [16]. It is advisable that the makers of the current $\mathrm{P} 2 \mathrm{P}$ regulations (including: China Banking and Insurance Regulatory Commission, Ministry of Industry and Information Technology, Ministry of Public Security, Cyberspace Administration, State Administration for Market Regulation) should cooperate with the China National Intellectual Property Administration to supplement and formulate regulations based on the Interim Measures [17]. It should first give the definition of IP internet financing to clarify its commonalities and differences with P2P online lending, and then take the following measures specifically for the differences.

Firstly, it should assign the positioning of "credit intermediary" to intellectual property internet financing, while allowing it to perform certain "credit intermediary" functions. As IP internet financing is based on Intellectual property rights, the essential characteristics of providing guarantees or credit enhancement for financing makes it inevitably related to financing credit. Only when it is not prohibited from performing part of the "credit intermediary" function can it be reserved institutional space for legal existence.

Secondly, it should be clarified that the IP internet financing do not undertake the aforementioned three prohibitions assumed by $\mathrm{P} 2 \mathrm{P}$ online lending. Foreign experience has shown that a diversified risk sharing mechanism that provides guarantees or promises to guarantee capital and interest by guarantee companies and insurance funds can effectively promote IP financing. If IP internet financing is forbidden to "directly or in a disguised form to provide guarantees or promise to guarantee principal and interest", the institutional basis for building a diversified risk sharing system might be lost. Moreover, providing guarantees to lenders with Intellectual property rights is a prerequisite for IP pledge financing; securitization of Intellectual property rights is a prerequisite for IP securitization financing; and investing in equity at the price of intellectual property is a prerequisite for IP equity-based crowdfunding. If IP internet financing is prohibited from "directly or in disguised form providing guarantees or promises to guarantee principal and interest", or "carry out asset-like securitization business", or "engagement in equity-based crowdfunding", IP financing through the Internet will lose the legal space for existence and development. 
Thirdly, the intellectual property information used to increase financing credit shall be included in the scope of legal disclosure of information by IP internet financing. In the light of the fact that IP internet financing is based on intellectual property rights, it should be clarified that all information related to Intellectual property rights that may affect the lender's decision-making is within the scope of information disclosure by the platforms. This information including but not limited to: the ownership, authorization, transferability and substitutability of the intellectual property; the market situation of related products or services; the use of the intellectual property for pledge and securitization; the valuation of the intellectual property, post-investment management, and the withdrawal and use of risk reserves; related information with IP financing or management agencies and professional IP operating agencies.

In addition, in terms of filing procedures, to facilitate supervision, besides requiring IP internet financing platforms to register with local financial regulatory authorities in accordance with the procedures specified in the Interim Measures, they should also be required to register with the competent IP authorities for filing. P2P online lending institutions that have not been registered by the competent authority of intellectual property rights should be prohibited from engaging in IP internet financing services.

\section{CONCLUSION}

The credit of SMEs plays a positive role in the financing satisfaction rate. Allowing intellectual property rights to become the basic assets and the source of funds for financing returns for financing technology-based SMEs could effectively increase their credit, thereby improving their financing capabilities and efficiency [18]. Allowing intellectual properties to be used as a guarantee or credit enhancement for its main body's could give play to the property capacity of intellectual property, making it a tool of public policy. It not only solves the financial difficulties of the main body, but also promotes the transformation of scientific achievements and technological innovation [19]. Small, medium and micro enterprises contributed $50 \%$ of China's tax revenue, $60 \%$ of GDP, $70 \%$ of invention patents, more than $75 \%$ of technological innovation, more than $80 \%$ of new products. They also absorbed more than $70 \%$ of rural migrant labour, provided $80 \%$ of city jobs, accommodated $90 \%$ of new jobs. However, many of them are faced with financing difficulties [20]. IP internet financing provides a new effective method to solve problems by relying on the value of the intellectual properties to improve the borrower's repayment credit. To allow the unique function of IP internet financing to have its full play, the government should cooperate with the China National Intellectual Property Administration to supplement and formulate regulations, based on current ones with $\mathrm{P} 2 \mathrm{P}$ online lending. The three prohibition of No. 3, 8 and 12 in Article 10 of the Interim Measures should be excluded to the supervision of IP internet financing platforms. IP information used for credit enhancement should be added into the scope of statutory disclosure information. While providing online financing services such as IP equity-based crowdfunding or IP securitization, IP internet financing platforms should also undertake the legal obligations determined by relative authorities.

\section{REFERENCES}

[1] Feng Xiaoqing. (2012). Research on my country's Enterprise Intellectual Property Pledge Financing and Its Improvement Countermeasures. Hebei Law (12), 39-46. DOI: 10.16494/j.cnki.10023933.2012.12.002.

[2] Wang Yu \& Jiang Huan. (2015). Analysis of China's Internet Finance Supervision Countermeasures. research of finance and accounting (01), 55-58. DOI: CNKI: Sun: LKHL.0.2015-01-020.

[3] Yang Dong. (2015). Internet financial risk regulation path. Chinese Law (03), 80-97. DOI: 10.14111/j.cnki.zgfx.2015.03.005.

[4] He Shiyuan. (2015). The correlation between the new business form of "Internet + Finance" and the development of the real economy. Reform (07), 72 81. DOI:CNKI:SUN:REFO.0.2015-07-009.

[5] Wang Lihua, Han Junhua \& Gan Shengdao. (2016). Research on Internet Finance Support for Technology-based Small and Micro Enterprises. Scientific Management Research (02), 95-99. DOI: 10.19445/j.cnki.15-1103/g3. 2016.02.024.

[6] Liu Jie. (2015). Risks in the operation of intellectual property Internet financing platforms and their decentralized countermeasures. Intellectual Property (09), 68-72. DOI: CNKI:SUN:ZSCQ.0.2015-09012.

[7] Han Chifeng \& Zhang Zhaoyong. (2015). Swedish patent pledge system and its reference. Intellectual Property (10), 136-140. DOI: CNKI:SUN:ZSCQ.0.2015-10-023.

[8] Zeng Li \& Wang Ming. (2016). The experience and enlightenment of intellectual property pledge financing of technology-based small and mediumsized enterprises in the United States and Japan. Chinese Certified Public Accountant (10), 101-105. DOI: 10.16292/j.cnki.issn1009-6345.2016 .10.021. [9] C. Baier, J-P. Katoen, Principles of Model Checking, MIT Press, 2008.

[9] Wei Qiong \& Lu Jinpeng. (2017). Risks and Legal Regulation of Internet Pledge Financing of 
Intellectual Property Rights. New Finance (06), 5357. DOI: CNKI: Sun: XJRO.0.2017-06-011.

[10] Feng Xiaoqing. (2012). Research on my country's Enterprise Intellectual Property Pledge Financing and Its Improvement Countermeasures. Hebei Law (12), 39-46. doi:10.16494/j.cnki.10023933.2012.12.002.

[11] Ma yi. (2018). intellectual property financing innovation under the development of internet finance. economic system reform (03), 132-137. DOI: CNKI: sun: jjtg.0.2018-03-021.

[12] Yin Jianfeng \& Liu xuedan. (2018). outline of criminal law regulation of internet equity crowdfunding. legal science (journal of northwest university of politics and law) (01), 89-99. DOI: 10.16290/j.cnki.1674-5205.2018.01.009.

[13] Huang Yong. (2015). Research on Legal Risk Prevention Mechanism of Intellectual Property Asset Securitization. Political and Legal Forum (06), 138-145. DOI: CNKI: sun: zflt.0.2015-06-014.

[14] Nan Xingheng \& Jing Tian. (2020). risk diversification path of intellectual property pledge financing. research on science and technology management (04), 206-211. DOI: CNKI: sun: kjgl.0.2020-04-026.

[15] Song Wei\&Hu Haiyang. (2009). Research on Risk Dispersion Mechanism of Intellectual Property Pledged Loan. Intellectual Property (04), 73-77. DOI: CNKI: Sun: ZSCQ.0.2009-04-014.

[16] Zhang Boyou. (2009). Risk Decomposition and Step-by-Step Control of Intellectual Property Pledge Financing. Intellectual Property (02), 30-34. DOI: CNKI: Sun: ZSCQ.0.2009-02-005.

[17] Chen Jianli. (2011). Risk Control of Intellectual Property Pledge Financing of Small and Mediumsized Technology Enterprises. Economic Horizon (07), 113-116. DOI: 10.16528/J.CNKI.221054/F.2011.07.020.

[18] Sun Rui ting \& Xiong Xueping. (2018). Research on the Influencing Factors of Internet Financing Satisfaction Rate of Small and Micro Enterprises - Based on the Data of Internet Platform Project Financing of 612 Enterprises. Finance and Economics (04), 59-64. DOI: 10.19622/J.cnki.cn361005/F.2000.

[19] Yi Ji Ming. (2011). the three-dimensional value of property rights-on the happiness of property in life. legal research (04), 74-85. DOI: CNKI: sun: laws.0.2011-04-006.
[20] Lu Jinsong. (2015). Thoughts on financing difficulties and expensive problems of SMEs. Financial Research (11), 115-123. DOI: CNKI: Sun: JRYJ.0.2015-11-008. 